\title{
PEMBELAJARAN BERMAKNA UNTUK MENCAPAI PENDIDIKAN KARAKTER
}

\author{
ADY FERDIAN NOOR \\ Dosen Pada Fakultas Keguruan dan IImu Pendidikan Prodi PGSD Universitas Muhammadiyah \\ Palangkaraya
}

\begin{abstract}
ABSTRAK
Permen Diknas Nomor 41 Tahun 2007: Standar Proses untuk Satuan Pendidikan Dasar dan Menengah: Pelaksanaan kegiatan inti merupakan proses pembelajaran untuk mencapai Kompetensi Dasar (KD) yang dilakukan secara interaktif, inspiratif, menyenangkan, menantang, memotivasi peserta didik untuk berpartisipasi aktif, serta memberikan ruang yang cukup bagi prakarsa, kreativitas, dan kemandirian sesuai dengan bakat, minat dan perkembangan fisik serta psikologis peserta didik.

Kegiatan pembelajaran dalam pendidikan karakter tidak hanya sekedar proses penyampaian materi saja, akan tetapi diselenggarakan untuk membentuk watak, peradaban, dan meningkatkan mutu kehidupan peserta didik. Pembelajaran diarahkan untuk mendorong pencapaian kompetensi dan perilaku khusus supaya setiap individu mampu menjadi pembelajar sepanjang hayat dan mewujudkan masyarakat belajar (Depdiknas, 2002).

Prinsip pembelajaran bermakna mendasari setiap langkah pembelajaran bermakna untuk mencapai pendidikan karakter, Menurut aliran behavioristik, belajar pada hakikatnya adalah pembentukan asosiasi antara kesan yang ditangkap pancaindra dengan kecenderungan untuk bertindak atau hubungan antara Stimulu-Respons (S-R). Belajar adalah upaya untuk membentuk hubungan S-R sebanyak-banyaknya (Sanjaya, 2008). Langkah-langkah pembelajaran bermakna sebagai berikut: 1) Belajar melalui lingkungan sekitarnya; 2) Membuat peta konsep; 3) Memberikan masalah untuk dipecahkan secara kelompok kecil (4-5 orang); 4) Diskusi untuk membuat keputusan bersama berdasarkan pengalaman masing-masing; 5) Inquiri; 6) Melaksanakan latihan-latihan.
\end{abstract}

Kata Kunci: Pembelajaran Bermakna, Pendidikan Karakter

\section{PENDAHULUAN}

Pada zaman dahulu era 40-an (saya belum lahir) sampai 80 -an (saya sudah lahir ke muka bumi) orang bersekolah adalah harus dapat menguasai ilmu yang diajarkan disekolah mulai dari ilmu teoritis sampai praktis. Itupun didukung oleh sarana dan prasarana yang serba terbatas/minim...mulai dari media pembelajaran, alat-alat pembelajaran, dan alat belajar dan peraga.

Saya teringat tentang buku tulis yang harus ditulis dan dihapus lagi karena itu diperlukan kognitif yang tinggi, juga para pendidik yang sebagian besar berbahasa belanda, arab, jepang, dan china maka psikomotor berbahasa sangat diasah sehingga kita bisa melihat neneknenek dan kakek-kakek kita hanya menguasai salah satu bahasa tersebut malah bukan bahasa Indonesia, dan yang terakhir adalah pelajaran budi pekerti yang sekarang mulai tergeser ataupun terlupakan, kenapa? Pelajaran dari ranah afektif ini dulu sangat dijunjung tinggi mulai dari menghormati guru dan orang tua sampai cara berpacaran pun ada nilai-nilai norma yang harus ditaati.

Semua ranah/aspek sangat diperhatikan, saya teringat ketika mendikbud masih dijabat oleh Fuad Hasan dan mendiknas oleh Malik Fajar, beliau-beliau adalah orang-orang yang sangat 
senang mengunjungi daerah-daerah pelosok untuk melihat perkembangan dunia pendidikan dengan ketiga aspeknya tersebut disana sehingga dapat dibuatkan strategi pembelajaran melalui pendekatan dan model pembelajaran yang efektif dan efisien melalui pengembangan kurikulum yang sesuai dengan situasi dan kondisi daerah pada saat itu. Maka saya sangat senang melihat rencana program mendikbud saat ini $\mathrm{M}$. Nuh yang salah satunya akan mengurangi kesenjangan perkembangan pendidikan didaerah-daerah pelosok/terpencil dengan daerah perkotaan/maju.

Mengurangi kesenjangan berarti akan ada pemerataan pembangunan bidang pendidikan yang selama ini telah lama ditunggu oleh wilayah-wilayah timur Indonesia. Wilayahwilayah timur Indonesia banyak memiliki mahasiswa yang mampu berkompetisi dengan mahasiswa wilayah Jawa dalam segala bidang. Kompetisi karena adanya kompetensi yang baik perlu didukung oleh lembaga yang berstandar nasional kalau perlu international. Standar perguruan tinggi yang dilakukan oleh Badan Akreditasi Nasional Perguruan Tinggi (BAN-PT).

Problem yang terjadi saat ini adalah fokus siswa mengejar nilai ujian nasional dan guru mengembangkan strategi pembelajaran yang mengarah kepada kepuasan mendapatkan nilai tinggi (kognitif saja). Hal itu mendorong para orang tua mengikutkan anak-anaknya les kesana kemari bagi yang mampu agar mencapai nilai ujian nasional, bagi siswa yang kurang mampu hanya berharap dari pihak sekolah yang mengatur strategi pembelajaran agar mencapai nilai yang diharapkan (sebagaimana yang bisa kita lihat dalam berita-berita di televisi dan koran bahwa banyak guru-guru yang tertangkap karena menolong peserta didiknya). Pihak sekolah mengejar target dari kepala dinas yang mengejar target dari gubernur harus memiliki tingkat kelulusan siswa diatas 95\%. Karena semakin banyak siswa mendapat nilai diatas rata-rata nilai ujian nasional maka menjamin kelulusan semakin banyak.

Aspek kognitif yang berfokus pada "yang penting mendapat nilai baik" membuat aspek afektif dan psikomotor terlupakan. Semua pihak tidak lagi berpikir bagaimana proses pembelajaran semua aspek terjadi disekolah maupun diluar sekolah, yang penting nilai bagus. Makanya saya tidak setuju dengan adanya program kerja 100 hari...??? pertanyaannya untuk apa? Sedangkan kalau kita lihat negara-negara maju mereka membuat blue print/rencana program pembangunan mereka setiap sepuluh tahun sehingga terjadi pembangunan yang berkelanjutan seperti zaman Pak Soeharto dulu yang bisa mencapai swasembada pangan, membuat pesawat sendiri dan banyak lagi prestasi-prestasi yang pernah kita capai dengan REPELITA.

Proses pembelajaran sekarang diperintahkan oleh Presiden Republik Indonesia saat ini Bapak Sosilo Bambang Yudhoyono bahwa peserta didik selain menguasai keilmuwan harus menguasai life skill (kecakapan hidup) untuk berwirausaha yang berarti sudah ada kemajuan dalam berpikir dalam rangka memperhatikan kemampuan siswa untuk bersosialisasi dengan masyarakat dan industri kerja. Kecakapan hidup memang membuat siswa menjadi lulusan yang "plus" tetapi jangan lupa bahwa keterampilan hidup yang memang diperlukan dalam masyarakat dan dunia kerja. 
Kecakapan hidup memerlukan desain pembelajaran yang direncanakan sesuai dengan situasi dan kondisi masyarakat sekitar.

Sekolah mendesain pembelajaran dengan membuat rencana strategi pembelajaran yang mempergunakan model pembelajaran Contextual Teaching and Learning (CTL) didukung dengan Kurikulum Berbasis Kompetensi (KBK) sekarang Kurikulum Tingkat Satuan Pendidikan (KTSP) sehingga siswa akan mendapatkan life skill/kecapakan hidup. Pendekatan kontekstual harus diimbangi oleh evaluasi yang tepat sehingga fase-fase /sintaks pendekatan kontekstual yang diterapkan dapat memunculkan daya kreativitas siswa. Evaluasi autentik adalah penilaian yang diterapkan dalam sintaks kontekstual. Penilaian yang memfokuskan pada proses bukan pada hasil (Samani, 2007).

Semua itu tidak akan berhasil apabila manajemen yang ada di sekolah sama semua. Michel Porter, kegagalan terbesar dalam manajemen adalah menerapkan manajemen yang seragam untuk kondisi organisasi yang berbedabeda. Oleh karena itu sekolah harus diberi "ruang gerak" untuk mengelola dirinya sendiri, dengan pola manajemen yang sesuai dengan situasinya. Prinsip inilah yang mendasari Manajemen Berbasis Sekolah (MBS) (Samani, 2007).

\section{PEMBELAJARAN BERMAKNA}

Untuk apa anak harus sekolah? Dalam arti akan menjadi peserta didik. Pertanyaan ini terkadang tidak begitu berarti seperti masuk kuping kanan keluar kuping kiri...tidak ada maknanya. Untuk mencapai makna peserta didik maka diperlukan pembelajaran yang bermakna. Pembelajaran bermakna artinya pembelajaran yang apabila peserta didik lulus dari sekolah itu apakah dia mendapatkan pendidikan karakter (kognitif, afektif dan psikomotor). Permen Diknas Nomor 41 Tahun 2007: Standar Proses untuk Satuan Pendidikan Dasar dan Menengah: "Pelaksanaan kegiatan inti merupakan proses pembelajaran untuk mencapai Kompetensi Dasar (KD) yang dilakukan secara interaktif, inspiratif, menyenangkan, menantang, memotivasi peserta didik untuk berpartisipasi aktif, serta memberikan ruang yang cukup bagi prakarsa, kreativitas, dan kemandirian sesuai dengan bakat, minat dan perkembangan fisik serta psikologis peserta didik." Jangan sampai terjadi pertanyaan dari beberapa orang penduduk desa, apakah nanti lulus anaknya bisa beli kambing? Padahal kalau tidak sekolah dia bisa beli dan mengembalakan akhirnya setiap tahun akan berkembang biak menjadi banyak.

WS. Rendra telah merasakan ketidak beresan pendidikan kita sejak tahun 1970-an seperti sepenggal kutipan dalam sajaknya yang berjudul Seonggok Jagung, 1975.

Pendidikan telah memisahkannya dari kehidupan Aku bertanya:

Apakah gunanya pendidikan

Bila hanya membuat seseorang menjadi asing di tengah kenyataan persoalannya?

Apakah gunanya pendidikan bila hanya mendorong seseorang menjadi layang-layang di ibukota kikuk pulang ke daerahnya?

Apakah gunanya seseorang belajar filsafat, sastra, teknologi, ilmu kedokteran, atau apa

Saja,

Bila pada akhirnya,

Ketika ia pulang ke daerahnya, lalu berkata:

"Di sini aku merasa asing dan sepi!" (dalam Samani, 2007).

Kerisauan juga dialami Robert T. Kyosaki, orang Jepang kelahiran Hawai yang terkenal dengan bukunya Rich Dad Poor Dad, juga 
mempertanyakan isi pendidikan di negaranya, dengan menulis buku yang dengan judul provokatif: If you want to be rich and happy, don't go to school. Dalam buku itu, Kyosaki menyimpulkan pendidikan selama ini tidak memberikan bekal untuk menghadapi kehidupan nyata. Walaupun terkesan bahwa Kyosaki mempersempit makna hidup dengan mencari kekayaan materi, tetapi ungkapannya tentang pendidikan sangat rasional (dalam Samani, 2007).

Beranikah kita bertanya sebagai orang tua dan sebagai diri kita sendiri, (seperti materi kuliah filsafat pendidikan yang diberikan oleh Warsono, Guru Besar Universitas Negeri Surabaya), waktu itu beliau memberikan pernyataan...apakah yang diberikan oleh sebuah lembaga pendidikan atau sebuah perguruan tinggi apabila kita membayar sekian dan sekian??? Beranikah kita bertanya tentang hal tersebut???).

Selanjutnya, sebenarnya apa yang kita inginkan ketika menyekolahkan anak? Umumnya menjawab "biar pandai, taat beribadah, berbakti kepada orang tua, dan dapat hidup sukses kelak di masa datang." Untuk itu kita perlu belajar kepada mereka yang telah merasakan kesuksesan. Ternyata mereka yang sukses adalah harus memiliki beberapa sifat sebagai berikut: beriman dan taat beribadah, jujur, menguasai bidang pekerjaan yang ditekuni, kerja keras, ulet dan pantang menyerah, kreatif, pandai memecahkan masalah, bertanggungjawab, berpengetahuan luas, pandai bekerjasama dengan orang lain, memiliki hubungan yang luas, berani mengambil risiko dan pandai mengambil keputusan, tegas dalam memimpin, suka menolong, toleran dan tidak usil terhadap urusan orang lain.
Maka sesuai dengan undang-undang Sistem Pendidikan Nasional nomor 20 Tahun 2003 menyatakan bahwa pendidikan adalah usaha sadar dan terencana untuk mewujudkan suasana belajar dan proses pembelajaran agar peserta didik secara aktif mengembangkan potensi dirinya untuk memiliki kekuatan spiritual keagamaan, pengendalian diri, kepribadian, kecerdesan, akhlak mulia, serta keterampilan yang diperlukan dirinya, masyarakat, bangsa dan negara. Namun filosofi pendidikan yang dirumuskan para ahli dan definisi pendidikan yang tercantum dalam UUSPN 20/2003 tersebut tidak terimplementasikan dalam praktik pendidikan di sekolah. Praktik pendidikan di sekolah telah direduksi menjadi sebuah proses mekanistik yang bertujuan untuk memasukkan mata pelajaran ke benak siswa, tanpa dipikirkan apakah itu akan menjadi bekal penting bagi kehidupan siswa di masa datang atau tidak.

Guru harus memastikan sebelumnya bahwa, 1) apakah siswa telah memiliki bekal awal yang memadai dan 2) apakah yang dibahas sesuai dengan perkembangan kognitifnya. Menurut Piaget setiap anak mengalami perkembangan kognitif, dari konkret ke abstrak. Pada tahap ke dua inilah yang mengharuskan guru menerapkan ciri pembelajaran kontekstual. Pembelajaran kontekstual dan pembelajaran yang menyenangkan sejalan dengan prinsip bahwa pembelajaran harus bermakna (meaningful learning). David Ausuble, pembelajaran haruslah bermakna bagi yang belajar, yaitu peserta didik. Artinya apa yang dipelajari harus bermanfaat bagi peserta didik (Samani, 2007). Bila dikaitkan dengan pendidikan, tentu tidak lepas dari istilah belajar. Belajar adalah suatu proses perubahan 
perilaku yang relatif bersifat menetap yang disebabkan oleh adanya pengalaman (Hitipeuw, 2009).

Pentingnya pembelajaran kontekstual tampaknya berkaitan dengan teori psikologi konstruktivis Vygotsky, intinya anak belajar dengan cara mengkonstruk sendiri pemahamannya terhadap apa yang dipelajari. Menurut teori ini, dalam pikiran anak terdapat peta konsep pikiran, yaitu semacam konsep pikiran yang bercabang dan satu sama lainnya dihubungkan oleh satu ide/gagasan/tema.

Tahap evaluasi, Sanjaya mengemukakan bahwa evaluasi merupakan suatu proses. Artinya, dalam suatu pelaksanaan evaluasi mestinya terdiri dari berbagai macam tindakan yang harus dilakukan. Dengan demikian evaluasi bukanlah hasil atau produk, akan tetapi rangkaian kegiatan. Untuk apa tindakan dilakukan? Tindakan dilakukan untuk memberi makna atau nilai sesuatu yang dievaluasi dan menunjukkan kualitas yang dievaluasi.

\section{PEMBELAJARAN BERMAKNA UNTUK MENCAPAI PENDIDIKAN KARAKTER}

Kegiatan pembelajaran dalam pendidikan karakter tidak hanya sekedar proses penyampaian materi saja, akan tetapi diselenggarakan untuk membentuk watak, peradaban, dan meningkatkan mutu kehidupan peserta didik. Pembelajaran diarahkan untuk mendorong pencapaian kompetensi dan perilaku khusus supaya setiap individu mampu menjadi pembelajar sepanjang hayat dan mewujudkan masyarakat belajar (Depdiknas, 2002).

Pembelajar sepanjang hayat dan mewujudkan masyarakat belajar, dengan konteks yang demikian pihak sekolah dalam konteks pendidikan karakter harus berperan sebagai kawah candradimuka untuk memberikan pengalaman belajar melalui latihan-latihan dalam memecahkan masalah baik secara individu maupun kelompok.

Pembelajaran bermakna direncanakan untuk mencapai pendidikan karakter. Ada tiga prinsip penting untuk pembelajaran bermakna, yaitu 1) Menurut Piaget, struktur kognitif akan tumbuh manakala peserta didik memiliki pengalaman belajar. Oleh karena itu, proses pembelajaran menuntut aktivitas peserta didik secara penuh untuk mencari dan menemukan sendiri (berpikir); 2) Pengetahuan diciptakan dan dibentuk oleh pikiran individu itu sendiri, sedangkan objek yang dipelajari hanya bertindak sebagai media saja; 3) Melalui pergaulan dan hubungan sosial, anak akan belajar lebih efektif dibandingkan dengan belajar yang menjauhkan dari hubungan sosial. Bettencourt (1985) mengemukakan bahwa mengajar dalam pembelajaran berpikir adalah berpartisipasi dengan peserta didik dalam membentuk pengetahuan, membuat makna, mencari kejelasan, bersikap kritis, dan mengadakan justifikasi (dalam Sanjaya, 2008).

Prinsip pembelajaran bermakna mendukung setiap proses pendidikan karakter yang diinginkan sesuai dengan KD dan SK yang telah ditentukan. Proses belajar adalah hakikatnya merupakan kegiatan perilaku dan sikap yang tidak dapat dilihat. Artinya, proses perubahan terjadi dalam diri peserta didik tidak dapat disaksikan. Kita hanya dapat melihat beberapa perubahan yang terjadi dari perilaku dan sikap peserta didik, ada perubahan dari perilaku dan sikap sebelumnya tidak. 
Prinsip pembelajaran bermakna mendasari setiap langkah pembelajaran bermakna untuk mencapai pendidikan karakter, Menurut aliran behavioristik, belajar pada hakikatnya adalah pembentukan asosiasi antara kesan yang ditangkap pancaindra dengan kecenderungan untuk bertindak atau hubungan antara Stimulu-Respons (S-R). Belajar adalah upaya untuk membentuk hubungan S-R sebanyak-banyaknya (Sanjaya, 2008). Langkahlangkah pembelajaran bermakna sebagai berikut: 1) Belajar melalui lingkungan sekitarnya; 2) Membuat peta konsep; 3) Memberikan masalah untuk dipecahkan secara kelompok kecil (4-5 orang); 4) Diskusi untuk membuat keputusan bersama berdasarkan pengalaman masingmasing; 5) Inquiri; 6) Melaksanakan latihanlatihan.

Pendidikan Karakter merupakan proses membantu generasi muda untuk menjadi manusia yang utuh dan penuh. Utuh dan penuh berarti menyangkut semua aspek dalam hidup manusia seperti: intelektualitas (kognitif), sosialitas, moralitas, emosi, afeksi, estetika, religiusitas, kepribadian, dan juga fisik. Semua itu merupakan aspek kompetensi yang perlu dibina dan dikembangkan. Pembelajaran mengenai hal tersebut sangat dibutuhkan dalam kehidupan pribadi, bermasyarakat, dan berkarya (Ayu, 2008). Melalui tahapan pembelajaran karakter yang telah saya buat, diharapkan mampu mengaktifkan peserta didik untuk mendapatkan kompetensi pendidikan karakter.

\section{KESIMPULAN}

Koentjaraningrat

(1980:42) mengemukakan Suatu bangsa yang hendak menintensifkan usaha untuk pembangunan harus berusaha agar banyak dari warganya lebih menilai tinggi orientasi ke masa depan, dan demikian bersifat hemat untuk bisa lebih teliti memperhitungkan hidupnya di masa depan; lebih menilai tinggi hasrat explorasi untuk mempertinggi kapasitas berinovasi; lebih menilai tinggi orientasi ke arah achievement dari karya (sesuai materi yang disampaikan Prof. Dr. Warsono, M.S dalam perkuliahan IImu Kewarganegaraan dan Pendidikan Kewarganegaraan); dan akhirnya menilai tinggi mentalitet berusaha atas kemampuan sendiri, percaya kepada diri sendiri, berdisiplin murni dan berani bertanggung jawab sendiri.

Pendidikan karakter tidak akan berhasil, apabila pembelajaran tidak menerapkan pembelajaran bermakna dalam pembelajaran di sekolah melalui Kurikulum Tingkat Satuan Pendidikan (KTSP). KTSP telah memberikan otonomi untuk menyelenggarakan pembelajaran berdasarkan situasi dan kondisi sekolah dan tidak menyimpang dari peraturan dan norma-norma yang berlaku di masyarakat.

\section{DAFTAR PUSTAKA}

Al. Muchtar, dkk, 2009, Strategi Pembelajaran PKn, Jakarta: UT

Cak/c8/ttg."Gadis 12Th Tuntut Rp 9,3 M". Dalam Jawa Pos. 5 April 2010. Hal International: Surabaya

Diknas, Permen Diknas Nomor 41 Tahun 2007 tentang Standar Proses untuk Satuan Pendidikan Dasar \& Menengah 
Jarolimek, dkk, 1993, Teaching \& Learning in The Elementary School, United States of America: Macmillan Publishing Company

Koentjaraningrat, 1980, Kebudayaan Mentalitet dan Pembangunan, Jakarta: PT Gramedia

Noor, Ady Ferdian, 2011, Laporan Pelatihan Singkat Luar Negeri Program BERMUTU di Ohio State University (OSU), Columbus, Ohio, Amerika Serikat

Samani, Muchlas, 2007, Mengagas Pendidikan Bermakna (Integrasi Life Skill-KBK-CTLMBS), Surabaya: SIC

Sulang, Kusni. Opini: "Pendidikan: Benteng Kebudayaan Bangsa." dalam Kalteng Pos. 8 Maret 2010: Palangka Raya

S_bio_0606459_chapter2.pdf(secured), UPI, Bandung, 2012, 16 April 2012 